Espacio, Tiempo y Forma, Serie III, H. Medieval, t. 12, 1999, págs. 101-138

\title{
Los animales en los textos sagrados del Islam
}

\author{
Aurora Ribagorda Calasanz
}

\begin{abstract}
RESUMEN
A través de los textos sagrados del Islam, fundamentalmente el Corán y la Sunna, este trabajo quiere subrayar la importancia del animal en el contexto religioso islámico. También se consideran las interpretaciones de la ley y el pensamiento jurídico de las diferentes escuelas, con especial atención al derecho islámico en alAndalus. Finalmente se aborda el problema de la creación artística y la representación figurativa de seres vivos bajo el punto de vista de su fundamento jurídico y religioso. La conclusión remitirá

a un hecho: la indisociabilidad entre hombre y animal en el mundo islámico.
\end{abstract}

\begin{abstract}
Studying the sacred tests of Islam, bassically the Koran and the Sunna, this work intends to show the important role of the animals in the world of islamic religion. Considerations are also made about this role in regard with the islamic laws and its different interpretations and judicial doctrines following the differents schools. Special interest is brought to the islamic law in al-Andalus. Finally this work deals with artistic creation and representation of live beings submitted to the religious and judicial rules of Islam. A conclusion will be underlined: the very closed links between men and animals in the islamic world.
\end{abstract}

El presente trabajo tiene el propósito de examinar la presencia de los animales en los textos sagrados del Islam ${ }^{1}$ y forma parte de un proyecto más amplio que analizará el papel desempeñado por la fauna en la civilización islámica.

1 Este artículo es un resumen del Trabajo de Investigación de Doctorado, realizado para el Departamento de Historia Medieval de la UNED por Aurora RIBAGORdA CALASANZ, Licenciada en Geografía e Historia, con el título Los animales en los textos sagrados del Islam. Madrid, 1999. 148 pág. 
Tres son los textos en los que se apoya el Islam: el Corán, la Sunna y la Sariah. El Corán es el Libro Sagrado de los musulmanes y constituye la fuente del dogma, de la ley y la base sobre la que se asienta todo el proceder islámico. La Sunna es la ortodoxia del Islam y se configura a base de un conjunto de Tradiciones - hadits-relativas a los actos y dichos de Mahoma y actua como refrendo y explicación del texto coránico. Finalmente, la Sari'ah recoge los fundamentos de derecho islámico que se establecieron con posterioridad al Libro Sagrado.

A partir de estos tres textos surgieron varias interpretaciones de la ley que dieron origen a diferentes escuelas jurídicas, formando todo ello un corpus de disposiciones que constituyen los fundamentos del islamismo.

En una sociedad nómada y beduina como la islámica, los animales han desempeñado un papel de gran importancia, tanto desde el punto de vista de su utilidad -transporte, alimento, fuerza de trabajo-como de las numerosas regulaciones que sobre ellos existen - prohibiciones alimentarias, inmolaciones rituales, impuestos, sacrificios-. A ello debemos añadir lo que parece haber caracterizado la actitud posterior del Islam hacia los animales: la representación figurativa.

Un aspecto que merece destacarse de antemano es la dificultad de hallar documentos suficientes para elaborar un estudio completo acerca de las regulaciones islámicas sobre animales. Los escasos textos específicos con los que se cuenta presentan una doble complicación: por un lado no están traducidos del árabe y por otro, están incompletos y acusan escaso rigor. Hay que recalcar que este aspecto sólo se refiere a textos sagrados pues para todo aquello relacionado con animales en cuanto a pintura, escultura, arte zoomórfico, tejidos, literatura, leyendas, representaciones figuradas, etc. etc... la bibliografía es abundante.

El desconocimiento de la lengua árabe ha dado a este trabajo una dificultad añadida. Por ejemplo, para todo lo concerniente a las interpretaciones de la ley-Siismo, Jariyismo, Mutaliza, Hermanos de la Pureza, etc... - ha sido necesario recurrir a traducciones más o menos modernas de las fuentes árabes para llegar finalmente a la conclusión de que los textos más válidos y de obligada consulta se reducen apenas a media docena de autores. En el caso concreto de las Tradiciones del profeta - los hadits -, el problema se agudiza pues sólo se ha encontrado una seria traducción realizada en fecha lejana -1964- por un gran especialista ${ }^{2}$, que no ha sido aún actualizada.

2 EL-BOKHARI. L'authentique Tradition Musulmane. Choix de hadiths. Traduits de l'arabe et presentés para G.H. Bousquet. Ed. Grasset et Frasquelle, Paris, 1964 (Sinbad). 
A pesar de ello, el trabajo de investigación que se ha llevado a cabo ha pretendido ser fiel reflejo del pensamiento islámico con sus ortodoxias y heterodoxias en relación con los animales analizando su presencia en los textos sagrados del Islam antes citados para poder ahondar posteriormente en las consecuencias que trajo la rigurosa aplicación de esos textos en relación con la fauna, su influencia sobre las sociedades humanas y en la visión cosmogónica del Islam.

\section{EL LIBRO SAGRADO: EL CORÁN}

Para el musulmán el Corán no es la palabra humana sino la palabra de Dios recitada por Gabriel a un enviado especial, Mahoma. Junto con el Evangelio y la Torá conforma el grupo de las religiones reveladas, de modo que podría decirse que buena parte de la religión de la Humanidad es la historia de los envíos de profetas a los diferentes pueblos: Noe, Abraham, Moisés... Los musulmanes consideran que Jesucristo fue el penúltimo de los enviados y Mahoma el último profeta antes de la llegada de Dios. El Corán es, por tanto, el texto sagrado válido hasta el día de la Resurrección.

El texto actual de el Corán se divide en 114 capítulos o suras, cada una de ellas compuesta de un número determinado de aleyas o versos. A su vez, existe una diferenciación entre los textos predicados en la Meca (612-622) y los textos predicados en Medina (622-632). Los musulmanes conceden gran importancia al orden histórico en el que se han predicado las suras por lo que, además de la distinción entre suras mecanas y medinesas, observan si una ha sido predicada antes que otra pues al haberse cambiado en algunos puntos la legislación coránica en vida aún de Mahoma, una aleya puede sustituir a otra más antigua, lo que es fundamental para el derecho islámico.

No fue Mahoma quién escribió el Libro Sagrado y algunos mantienen la creencia de que lo escribieron sus Compañeros. Lo que sí se sabe a ciencia cierta es que el Corán fue escrito en los soportes más diversos: piedras planas, omoplatos de camello, etc... Sería Utman, tercer sucesor del Profeta quién establecería, alrededor del año 650, una edición oficial de el Corán que es la que, a pesar de las modificaciones que ha sufrido, ha permanecido inalterable hasta nuestros días ${ }^{3}$.

3 En este trabajo se ha utilizado como fuente la versión de E/ Corán de Julio Cortés. Ed. Herder 6 . $^{\mathrm{a}}$ ed. Madrid, 1998 y se ha seguido el criterio general de citar en primer lugar el número de la Sura y en subíndice el número o números de las aleyas en las que se han encontrado referencias a animales. Con el fin de no repetir en cada cita el nombre de la Sura y su procedencia se incluye en la Tabla 1 la numeración de las Suras con su correspondiente título y su procedencia mecana o medinesa. 


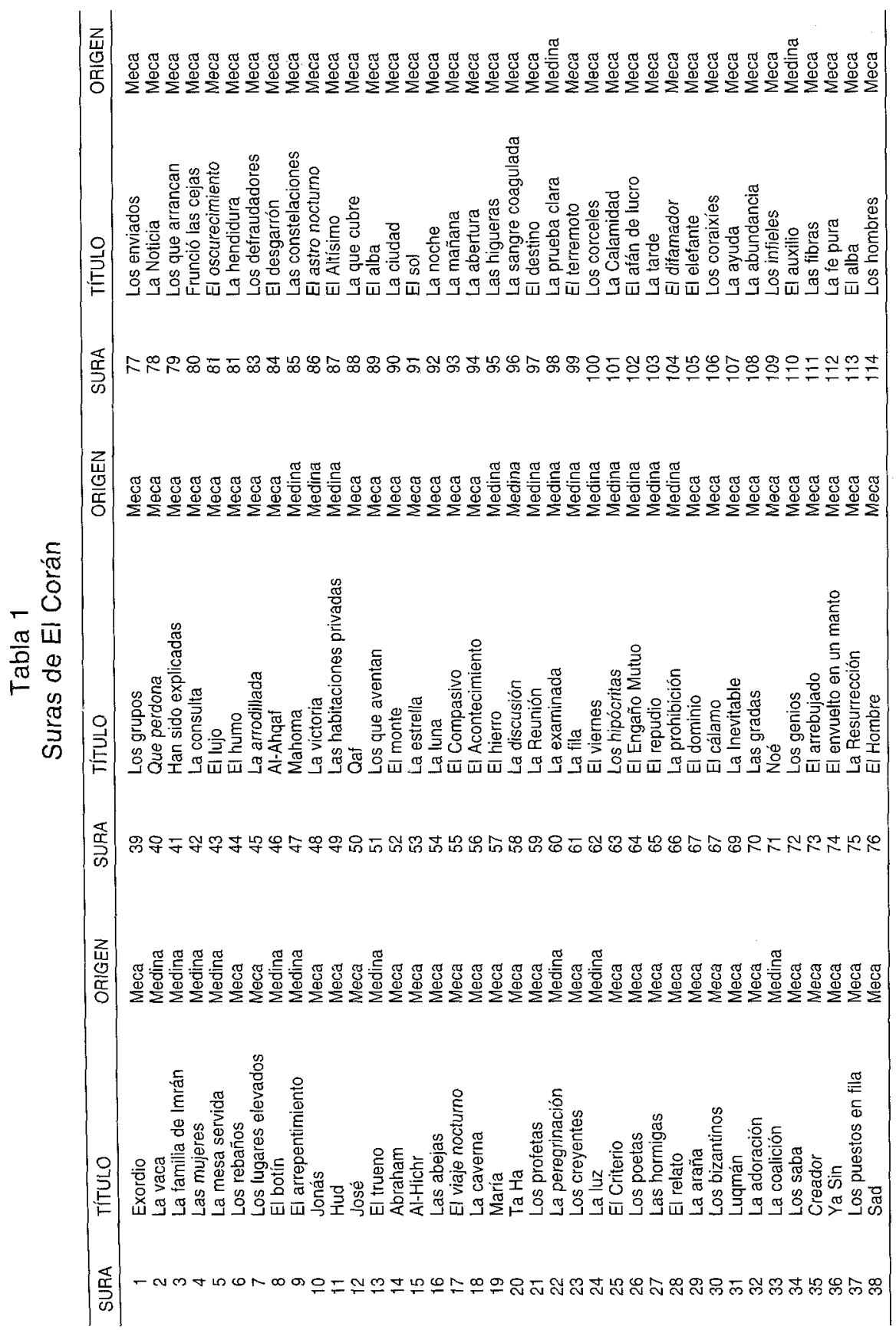


En el Corán aparecen diversos animales que se sitúan en el marco de la vida de los beduinos o de los cultivadores del oasis y que tienen múltiples significados. Con frecuencia se designa al ganado mayor y menor con un nombre genérico aunque en ocasiones se precise que se trata de caballos, asnos o mulos, la mayoría de las veces recalcando su utilidad, aspecto vital en un medio hostil como es el desierto. En otras ocasiones se mencionan especies en particular porque conforman una anécdota o parábola: la camella sagrada de los tamudeos, el lobo que devoraría a José, el pez de Jonás, la fragilidad de la tela de la araña, los pájaros creados por Dios que sólo Él sostiene... Otras veces tienen un sentido metafórico, siempre relacionado con el mensaje divino: Resurrección de las aves, bestias que aparecerán para anunciar el Juicio Final, castigos divinos concretados por metamorfosis en cerdos y monos para los impíos,... Otras tienen un amplio sentido figurado, como el Bicorne que alude a Alejandro Magno o Buraq, el caballo alado, etc...

He aquí algunos ejemplos representativos:

Aves

Son abundantes las Suras y aleyas que hablan de las aves y de los pájaros en sentido general, entre otras:

En cuanto a la Resurrección:

- C 2 : «Y cuando Abraham dijo: "¡Señor, muéstrame cómo devuelves la vida a los muertos! -Dijo: ¿Es que no crees?-Dijo: Claro que sí, pero es para tranquilidad de mi corazón-. Dijo: Entonces coge cuatro aves ${ }^{4} \mathrm{y}$ despedázalas. Luego pon en cada montaña un pedazo de ellas y llámalas. Acudirán a ti rápidamente (...)" ".

En relación con José y la interpretación del sueño de Faraón:

- C $12_{36-41}:(\ldots)$ “Con él (con José) entraron en la cárcel dos esclavos. Uno de ellos dijo: Me he visto (en sueños) prensando uva. Y el otro dijo: Yo me he visto llevando sobre la cabeza pan del que comían los pájaros. ¡Dános a conocer su interpretación! (...) ¡Compañeros de cárcel! (dijo José): Uno de vosotros escanciará vino a su señor. El otro será crucificado

Asimismo y para hacer más ágil la lectura de cada una de las Suras se ha suprimido la fórmula clásica con la que comienza cada una de ellas: "En el nombre de Dios, el Compasivo, el Misericordioso", es decir, el tekbir.

${ }^{4}$ Según la tradición, las cuatro aves son: un gallo, un pavo real, un pichón y un cuervo. 
y los pájaros comerán de su cabeza. Se ha decidido ya lo que me consultábais».

Relacionado con el poder de Dios:

- C $16_{79}$ : ¿¿No han visto (los hombres) las aves sujetas en el aire del cielo? Sólo Dios las sostiene. Ciertamente, hay en ello signos para gente que cree». También C $38_{18,19}$ y C $67_{19}$.

En relación con el entendimiento por Salomón del lenguaje de los pájaros:

- C 27 16-20: «Salomón heredó a David y dijo. ¡Hombres! Se nos ha enseñado el lenguaje de los pájaros y se nos ha dado de todo. ¡Es un favor manifiesto!»

Hay aleyas que se refieren al milagro de Jesucristo en cuanto a la Creación:

- C $3_{49}$ : "Y como enviado (Jesucristo) a los Hijos de Israel: Os he traido un signo que viene de vuestro Señor. Voy a crear para vosotros, de la arcilla, a modo de pájaros. Entonces, soplaré en ellos y con permiso de Dios, se convertirán en pájaros (...)». En el mismo sentido también C $5_{110}$.

\section{Caballo}

Es uno de los animales más citados en el Corán junto con el camello y los ovinos:

- C 3 ${ }_{14}:$ «El amor de lo apetecible aparece a los hombres engalanado: las mujeres, los hijos varones, el oro y la plata por quintales colmados, los caballos de raza, los rebaños, los campos de cultivo. Eso es breve disfrute de la vida de acá. Pero Dios tiene junto a sí un bello lugar de retorno».

Refiriéndose a los traidores, el Corán utiliza a la caballería en varias ocasiones:

- C $8{ }_{60}$ : «Preparad contra ellos toda la fuerza, toda la caballería que podáis para amedrentar al enemigo de Dios y vuestro y a otros fuera de ellos que no conocéis pero que Dios conoce! Cualquier cosa que gastéis por la causa de Dios os será devuelta, sin que seáis tratados injustamente". También C $17{ }_{64}$.

En cuanto a los beneficios divinos en relación con lo creado por Dios para el hombre y, en concreto, acerca de la montura: 
- C $16_{8}$ : «Y ha creado los caballos, los mulos, los asnos, para que os sirvan de montura y de ornato. $Y$ crea otras cosas que no sabéis".

En relación con los caballos de Salomón y de acuerdo con la tradición se dice que éste poseía mil corceles de raza. Embelesado en contemplarlos olvidó la oración de la tarde y, como penitencia, sacrificó a todos menos a cien. El Corán lo refleja:

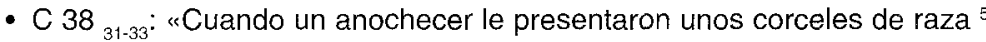
(...) Y dijo:. Por amor a los bienes terrenales he descuidado el recuerdo de mi Señor hasta que se ha escondido (el sol) tras el velo (de la tarde). ¡Traédmelos! Y se puso a desjarretarlos y degollarlos».

En relación con la expulsión realizada por Mahoma de una tribu judía medinesa - los Banu Nadir-

- C $59_{6}:$ : No habéis contribuido ni con caballos ni con monturas al botín que de ellos (de los Banu Nadir) ha concedido Dios a su enviado» 6 .

\section{Camella/o}

Ocupa el primer lugar entre todos los animales citados en El Corán. En él se menciona sólo el género camello de una sola joroba -dromedario-. Puede referirse a este animal en tres formas: el camello macho (chamal), la camella (naqa) y el camello sin especificar sexo (bair) y cuando lo hace, se refiere a él en variadas circunstancias.

La importante presencia de este animal en la civilización musulmana nos remite a la Arabia preislámica en donde existía una lotería árabe, el maysir, consistente en el reparto de las diversas partes de un camello previamente sacrificado. Para ello se utilizaban pequeñas flechas en las que se había escrito el nombre de cada uno de los participantes en el juego. Una vez introducidas en una bolsa se sacaban las flechas al azar y se lanzaban al camello. El lugar en donde se clavaba la flecha designaba la parte del cuerpo que había correspondido como premio al jugador. En ocasiones había partes de la res que no habían tocado a nadie; en ese caso se distribuía entre los pobres de la tribu ${ }^{7}$. El maysir quedó prohibido por la aleya $C 5_{90,91}$.

\footnotetext{
5 Según Julio Cortés la traducción literal sería: «caballos que se tienen sobre tres patas y tocan ligeramente el suelo con el borde del casco de la cuarta pata». Op cit. pág. 526.

6 El reparto del botín está autorizado por el Islam y reflejado ampliamente en elCorán: C $4{ }_{94}$,

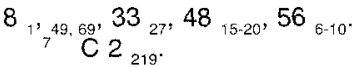


El Corán narra un episodio relacionado con la tribu árabe troglodita de los tamudeos que vivía en Arabia occidental antes de la llegada del Profeta; debido a su impiedad fue aniquilada por un cataclismo ${ }^{8}$. En varias ocasiones se narra el episodio de la muerte de una camella enviada por Dios a manos de los tamudeos porque se bebía toda el agua de la tribu. Así se cuenta:

- C $7_{73-77}:$ «(...) - Os ha venido de vuestro Señor una prueba: es la camella de Dios que será signo para vosotros. ¡Dejadla que pazca en la tierra de Dios y no le hagáis mal! Si no, os alcanzará un castigo doloroso (...) - Los dignatarios de su puebio, altivos, dijeron a los débiles que habían creído: - ¿Sabéis seguro que Salih (la camella) es enviada por su Señor? (...)- Los altivos dijeron: Nosotros no creemos en lo que vosotros creéis-. Y desjarretaron la camella (...) Y les sorprendió el Temblor y amanecieron muertos en sus casas». En este mismo sentido C $11_{64} ;$ C $17_{59} ;$ C $26_{155-157}$; C $54_{27-29}$; C $91_{13-15}$.

\section{Elefante}

El Historiador Procopio en De bello persico I, relata que durante el reinado de Justiniano (530 d.C) los abisinios conquistaron Yemen. Algunos años más tarde el emperador bizantino envió un embajada al rey abisinio incitándole a declarar la guerra a los persas, que fue desastrosa para los romanos. Abraha, el virrey abisinio cristiano del Yemen quiso atacar militarmente La Meca y organizó una expedición en la que figuraba un elefante. Una epidemia de viruela detuvo su marcha e hizo fracasar la expedición. Esta tuvo lugar hacia el año 530 según algunos autores y en el año 570 según la tradición islámica, siendo en este año cuando se cree que nació Mahoma.

El Corán narra este episodio de la siguiente forma, en una sura que lleva por título, precisamente, «El Elefante»:

- C $105_{1-5}$ : ¿ ¿No has visto cómo obró tu Señor con los del elefante? ¿No desbarató su artimaña y envió contra ellos bandadas de aves, que descargaron sobre ellos piedras de arcilla ${ }^{9}$ dejándolos como espigas desgranadas?».

\section{Hormigas}

Gozan de un papel simbólico:

- C 27 17.18: "Las tropas de Salomón, compuestas de genios, de hombres y pájaros, fueron agrupadas ante él y formadas. Hasta que, llegados al Valle

C 89

Es la epidemia de viruela que veíamos ut supra. 
de las Hormigas ${ }^{10}$, una hormiga dijo: ¡Hormigas! ¡ Entrad en vuestras viviendas no sea que Salomón y sus tropas os aplasten sin darse cuenta!»

Perro

Existe una leyenda oriental, común a cristianos y musulmanes relacionada con Siete Durmientes que se refugiaron en una caverna:

1. Leyenda cristiana. Los Siete durmientes de Efeso, jóvenes monoteístas, para escapar a una persecución de Decio (249-251) se refugiaron en la caverna de un monte en Efeso, (actual Turquía) ${ }^{11}$ permaneciendo dormidos en ella durante ciento noventa y seis años, para despertar en época de Teodosio II (408-450) cuando el cristianismo había sido proclamado religión de Estado.

2. Leyenda islámica: Para los islámicos, la persecución de los Siete Durmientes tuvo lugar bajo Trajano (98-117) despertando los durmientes trescientos nueve años después, bajo Teodosio II.

El Corán refiere más o menos este episodio y se refiere al perro como guardián de esa caverna:

C $18_{9-26}:$ "(...) ¿Crees que los de la caverna y de al-Raqim ${ }^{12}$ constituyen una maravilla entre nuestros signos? (...) Y les hicimos dormir en la caverna por muchos años. Luego los despertamos para saber cual de los dos grupos calculaba mejor cuánto tiempo habían permanecido (...). Les hubieras creído despiertos cuando, en realidad dormían (con los ojos abiertos). Les dábamos vuelta a derecha e izquierda, mientras su perro estaba en el umbral con las patas delanteras extendidas. (...) Unos dirán: Eran tres, cuatro con su perro. Otros dirán: Eran cinco, seis con su perro. Otros dirán: eran siete, ocho con su perro (...)».

\section{PROHIBICIONES ALIMENTARIAS}

El Corán diferencia entre alimentos lícitos o puros - halal-, ilícitos o impuros - haram - y dudosos o censurables - makruh - estando repartida

10 Este Valle es mencionado por Ibn Battuta como situado en el puerto de Ascalón (ver lbn Battuta, A través del Islam. Alianza Universidad, 3. ${ }^{a}$ reim. 1997. pág. 155). Se trata de una de las cinco ciudades reales de los filisteos (Josué $13_{3}$ ), situada en la costa del Mediterráneo entre Gaza y Jamma a unos $70 \mathrm{Kms}$. de Jerusalén.

11 La atribución de la leyenda a ese lugar de Turquía se debe a la existencia de una necrópolis cristiana que pudo desarrollarse en época de las persecuciones. Para más información El Corán, nota de Julio Cortés págs. 351-352. METE, B. Ephese retrouvée. Ed. Ticaret Matbaacilik Türk Anonim Sirketi. Izmir (Turquie), págs. 89-90. Ephèse. Revaç, Turquie, 1997. págs. 47-48. Enciclopedia Universal llustrada. Tomo XVIII, 2. ${ }^{a}$ parte. págs. 2621-2622. Ed. Espasa Calpe, Madrid, 1923.

12 Algunos autores han considerado que al-Raqim era el nombre del perro. 
su clasificación a lo largo de todo el Libro. Basándose en ello, se elaboran las prohibiciones y permisiones dietéticas.

\section{Alimentos lícitos}

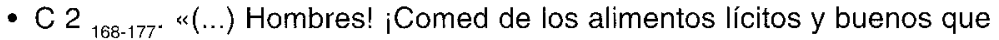
hay en la tierra y no sigáis los pasos del Demonio (...)!» También C $5_{87-88 \text {. }}$

- C $2_{173}$ "Si alguien se ve compelido por la necesidad (hambre) -no por deseo ni por afán de contravenir - no peca». También C $5_{93}, \mathrm{C} 6_{119} \mathrm{C} 1_{115^{\circ}}$.

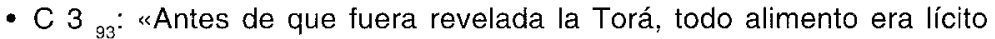
para los Hijos de Israel, salvo lo que Israel se había vedado a sí mismo".

- C $5_{4,5}:$ «(..) te preguntan qué alimentos les están permitidos. Di: (...) Podéis comer de lo que os cojan los animales de presa que habéis adiestrado para la caza, tal como Dios os ha enseñado. (...) Se os permite el alimento de quienes han recibido la Escritura así como también se les permite a ellos vuestro alimento" ${ }^{13}$.

- C $5_{96}$ : "Os es lícita la pesca y alimentaros de ella para disfrute vuestro $y$ de los viajeros (..)" .

- C $16_{10-16}$ : y C $35_{12}$ : «Él es quien ha sujetado el mar para que comáis de él carne fresca".

- C $52_{22}$ y C $56_{21}:$ «(..) con la carne de ave que les apetezca».

\section{Alimentos impuros}

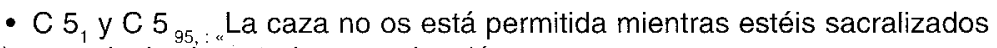
(...) ", es decir, durante la peregrinación.

- $\mathrm{C} 5_{3}$ "Os está vedada la carne mortecina, la sangre, la carne de cerdo, la de animal sobre el que se haya invocado un nombre diferente del de Dios, la de animal asfixiado o muerto a palos, de una caída, de una cornada, la del devorado parcialmente por las fieras - excepto si aún lo sacrificáis vosotros ${ }^{14}$ la del inmolado en piedras erectas.(...) ${ }^{15}$. También C $2_{173}, 5_{3-5,} 6_{118,119,145}$.

- C $5_{95}:$ «(..) Si uno de vosotros la mata deliberadamente (la caza), ofrecerá como víctima a la Kaaba, en compensación, una res de su rebaño, equivalente a la caza que mató (...)" ${ }^{16}$.

13 Existe unanimidad de criterio sobre la licitud del alimento de los judíos para el musulmán pero sin embargo no la hay respecto al de los cristianos.

14 Es decir, si se encuentra aún con vida.

15 En este caso son las piedras rituales usadas en la inmolación de las víctimas.

16 Según Julio CoRTÉs, El Corán, pág. 187, posteriormente se elaboró una escala de equivalencias: un cordero por una hiena, una cabra por una gacela. 


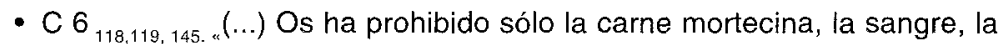
carne de cerdo y la de todo animal sobre el que se haya invocado un nombre diferente del de Dios".

\section{SACRIFICIOS}

El Islam es una continuación de todas las teologías monoteístas previas, las cuales, de acuerdo con el Corán ${ }^{17}$, han sido reveladas a través de los tiempos en todas las partes del mundo siendo el credo de Abraham la religión del Islam.

Es con estos antecedentes religiosos con los que el Islam ha continuado la tradición del sacrificio de animales y podría considerarse que la fuente base del concepto islámico de sacrificio es la versión coránica de sacrificio de Abraham: Éste fue ordenado por Dios a sacrificar a su hijo Isaac, accediendo ambos, padre e hijo, a llevar a cabo la orden. En el último momento, Dios detuvo a Abraham:

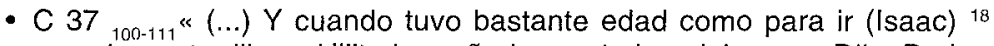
con su padre, este dijo: - Hijito he soñado que te inmolaba-. -Dijo: Padre, haz lo que se te ordena (..) - Cuando ya se habian sometido los dos (..) Le llamamos: Abraham, has realizado el sueño (...) Tu has cumplido la misión y por ello te recompensaremos (...)".

El acto de Dios de rescatar al hijo de Abraham con un carnero significa para los musulmanes la prohibición de los sacrificios humanos.

Varios son los versos de el Corán en los que se basa el sacrificio de animales:

- C 2 196: Llevad a cabo la peregrinación mayor y la menor por Dios. Pero, si os veis impedidos, ofreced una víctima conforme a vuestros medios. No os afeitéis la cabeza ${ }^{19}$ hasta que la víctima llegue al lugar del sacrificio. Si uno de vosotros está enfermo o tiene una dolencia en la cabeza, puede redimirse ayunando, dando limosna $u$ ofreciendo un sacrificio. Cuando estéis en seguridad, quien aproveche para hacer la peregrinación menor, mientras llega el tiempo de la mayor, que ofrezca una víctima según sus posibilidades. Pero, si no encuentra qué ofrecer, deberá ayunar tres días durante la peregrinación mayor y siete a su regreso, esto es, diez completos. (...)".

\footnotetext{
$17 \mathrm{C} 1_{164} ; 10_{47 ;} ; 3_{7} ; 16_{36} ; 35_{24}: 40_{78}$.

18 Isaac aunque no se le nombra en esta aleya es anunciado a Abraham en la C 37

19 Ritual de la peregrinación que marca el paso del peregrino del estado sacralizado (ihram) al estado profano.
} 
- C $5{ }_{97}$ : «Dios ha hecho de la Kaaba la Casa Sagrada (...) y ha instituido el mes sagrado (el de la Peregrinación), la víctima y las guirnaldas» ${ }^{20}$.

- C $22_{27,28}$ : «(..) iLlama a los hombres a la peregrinación (...) para atestiguar los beneficios recibidos y para invocar el nombre de Dios en días determinados ${ }^{21}$ sobre las reses de que Él les ha proveido. Comed de ellas y alimentad al desgraciado, al pobre".

- C $108_{1-3}:$ "Ora, pues a tu Señor y ofrece sacrificios".

El camello tiene su apartado específico:

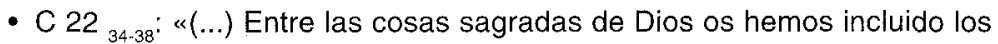
camellos de sacrificio. Tenéis en ellos bien. ¡Mencionad, pues, el nombre de Dios sobre ellos cuando están en fila (para ser sacrificados)! Y cuando yazcan sin vida ${ }^{22}$ comed de ellos y alimentad al mendigo y al necesitado. Así los hemos sujetado a vuestro servicio. (...) Dios no presta atención a su carne ni a su sangre (...)».

Un punto sobresaliente que se observa en estos versos es que el propósito principal de permitir a los musulmanes continuar con el sacrificio de animales es convertir ese rito en una institución de caridad. Ya hemos visto que todos los versos de el Corán que tratan este aspecto insinuan que la condición es que la carne sea para alimentar a los pobres, a los necesitados y a los mendigos.

A este respecto, hay que destacar que en algunas religiones, por ejemplo el animismo que se practica en determinadas islas de Indonesia y que convive con el cristianismo y el islamismo, se degüellan búfalos como ofrenda de sacrificio por el fallecimiento de una personalidad de clase alta como medio de liberar su alma, repartiendo posteriormente la carne de estos animales entre los habitantes del poblado ${ }^{23}$. Este aspecto de reparto de la carne junto con el sistema de degollamiento por corte de yugular (dabh) es coincidente con el islamismo.

\section{LA ORTODOXIA DEL ISLAM: LA SUNNA. LOS HADITS}

El Corán es la fuente-raíz del dogma y de la ley en el Islam. Por ello del "hecho coránico" se ha derivado una ingente tarea de indagación y

20 Guirnaidas que se colocaban al cuello de las victimas para distinguirlas de las que no iban a ser sacrificadas

21 Los diez primeros días del mes de la peregrinación.

22 Según Julio Cortés, Op cit. , pág. 397, la traducción literal sería «Cuando se desplomen sus costados».

23 Se ha comprobado este hecho personalmente, como testigo ocular en Sulawesi (Islas Célebes), en un viaje realizado al archipiélago indonesio en 1999. 
comentario que ha dado origen a las diversas disciplinas que se agrupan genéricamente bajo el nombre de «ciencias de el Corán».

La comunidad islámica o umma se divide en dos colectividades internas: por un lado la Sunna, considerada como la ortodoxia del Islam, y por otro, la Si'a, considerada a su vez como la heterodoxia.

Después de la muerte del Profeta se constituyó un conjunto de tradiciones relativas a sus actos, dichos, gestos, actitudes y silencios que durante mucho tiempo sólo fueron transmitidas por vía oral. La Sunna - costumbre, hábito, manera, - por lo tanto, constituye una "ciencia de la tradición" y actúa como explicación y refrendo del texto coránico. Se aplicaba tanto en derecho público como privado o en materia civil hasta que se convirtió en la segunda fuente jurídica del Islam.

La Sunna se configura a base de hadits, que son relatos breves, de fácil comprensión, muy popularizados y con un carácter sentencioso y proverbial, que conforman el arquetipo de musulmán ideal y el modelo de la comunidad musulmana. El hadit se divide en dos partes, el isnad que es el apoyo a la autenticidad del relato otorgado por la veracidad de los narradores y el matn que es un texto con un contenido que suele ser anecdótico.

Este corpus de tradiciones empieza a configurarse durante el siglo VII, aunque es durante los dos siglos siguientes cuando llega a constituirse definitivamente y especialmente en el siglo $x$. Son seis los extensos libros que han recopilado textos canónicos y que son generalmente admitidos como válidos por el mundo sunni:

1. Al Musamaf As-Sahib, llamado símplemente As-Sahib, de AlBokhari, que contiene más de 7.000 tradiciones.

2. Al Musannaf As-Sahih de Muslim Ibn Al-Haggag de Nisapur.

3. As-Sunan, de Abu Dawud de Siyistan.

4. Al-Yami de Abu Isa Muhammar Al-Tirmidi.

5. As-Sunan, de Abu Abd Allah Muhammad Ibn Maga de Qawzin.

6. As-Sunan de Abu Abdul Rahman Al Nasari,

existiendo muchas colecciones de Sunna y Hadits que no tienen el carácter de universal aceptación que poseen las citadas pues tienen su garantía en el isnad, que, como hemos visto, es la cadena de transmisión que asegura la fidelidad del testimonio inicial.

Realizar un análisis de todos los hadits existentes es tarea que plantea grandes dificultades no sólo por su elevado número (hay unos 7.500) sino 
también por las dudas que sobre su autenticidad alguno plantearía: Wensinck, especialista contemporáneo de esta cuestión ha cifrado en un $5 \%$ los hadits que realmente se remontan al Profeta mientras que otros como J.Schacht, consideran esta evaluación demasiado optimista. Además, hay que tener en cuenta que muchos de ellos son repetitivos y sensu contrario, otros muchos presentan contradicciones.

En los hadits aparecen preceptos morales, reglas jurídicas, indicaciones de orden ritual, prohibiciones, forma de tratar a los animales, etc... al igual que sucede en el Corán. Por ello, y para no caer en lo que Félix Pareja ${ }^{24}$ ha calificado como «tupida selva de las Tradiciones», se analizarán en este capítulo tan sólo una muestra de los hadits de El-Bokhari ${ }^{25}$, recopilados por Bousquet, que sirven para dar una visión muy válida de los diferentes sentidos en los que aparecen los animales en las Tradiciones.

La colección auténtica de hadits realizada por El-Bokhari fue traducida por O-Houdas entre los años 1913 y 1914 y consta de cuatro gruesos volúmenes aunque esta colección apenas está accesible para los no especialistas en la materia. Posteriormente, Bousquet ${ }^{26}$ realizó una nueva traducción en el año 1964 y es a ella a la que nos referiremos en este estudio.

Los animales aparecen abundantemente en los hadits y con significados diversos, siendo citados, en la mayoría de las ocasiones, en parábolas o metáforas, al igual que sucede en el Corán. Debido quizá a una traducción demasiado literal de los hadits, algunos animales tienen significados inciertos y de compresión difícil.

Los animales más citados son evidentemente, los de la fauna paleoártica y sobre todo aquellos que caracterizan las condiciones de vida nómadas, es decir, aquellos propias de una sociedad beduina: desierto, camellos y rebaños ${ }^{27}$.

24 PAREJA, F, Islamologia, Vol I., Ed. Razón y Fe, Madrid 1952-54. pág. 82.

25 El-Bokhari nació en Bukhara el 19 de julio del año 810 y murió en Samarkanda el 31 de agosto del año 870 . Su compilación reproduce literalmente el texto de la Tradición sin mezcla de razonamiento alguno, por lo que muchos hadits son dificiles de entender.

${ }_{25}$ EL-BokHARI. L'authentique Tradition Musulmane. Choix de hadiths. Traduits de l'arabe et presentés par G.H. Bousquet. Ed Grasset et Frasquelle, Paris, 1964 (Sinbad).

${ }_{27}$ Los números que aparecen al principio del hadit corresponden a la página y al número de la tradición en que se ha encontrado la referencia del animal, y que es la reflejada en la traducción de Bousquet. Los que aparecen al final del hadit corresponden: primero el capítulo, después la sección y tras la coma, el número de la tradición, según el esquema de la traducción de Houdas que Bousquet, asimismo, facilita. 


\section{Buraq}

La escatología musulmana sostiene que Mahoma realizó una ascensión celeste guiado por Gabriel y montado en un blanco caballo alado, Buraq. Es precisamente en las Tradiciones en dónde se habla de él ${ }^{28}$. En este sentido, el Corán no menciona a Buraq pero sí dedica la Sura 17 a este viaje iniciático nocturno ${ }^{29}$.

- (pág. 58, num. 26): «El Profeta ha dicho: Me encontraba cerca de la Kaaba en un estado intermedio entre la vigilia y el sueño, cuando alguien gritó: El hombre que se encuentra entre los dos otros. Me fue entregado un recipiente de oro repleto de sabiduría y fe; me abrí el cuerpo desde el esternón hasta el bajo vientre; después me lavé el vientre con agua del Zem-Zem ${ }^{30}$ y lo rellené después de sabiduría y fe. Una montura blanca me fue traida, más pequeña que la mula, más grande que el asno: era Buraq; entonces partí con Gabriel hasta el cielo» $(59-6,1)$.

Una gran parte de las tradiciones se halla reunida en dos antiguas versiones, latina y francesa de un manuscrito arábigo ${ }^{31}$ cuyo interés en lo que animales se refiere, podría resumirse asi:

Mientras Mahoma acompañado de Gabriel va cruzando los siete cielos ve a su derecha bellísimos ángeles y a su izquierda otros de aspecto horrible, todos ellos dirigidos por el ángel de La Muerte. Más arriba, Mahoma ve un ángel gigantesco en forma de gallo cuyas patas llegan hasta las profundidades de la tierra, su cresta hasta lo más alto del cielo y que con sus alas desplegadas abarca los cielos y la tierra en toda su amplitud.

En el caso de que se produzcan coincidencias o divergencias entre los hadits y El Corán en relación con algún animal, se citará la aleya correspondiente. Si no se hace mención expresa significa que el animal de que se trate no figura específicamente en ninguna aleya del Libro Sagrado.

Para hacer más ágil la lectura de los hadits se ha omitido en todos ellos la alabanza ritual, tekbir, que sigue al nombre del Profeta cada vez que es invocado: «A Él bendición y salud", o bien, «Alá sea loado».

28 Este viaje al mundo de ultratumba ha sido objeto de representaciones figuradas, sobre todo en miniaturas turcas de los siglos XIV y XVI como las que se conservan en la Biblioteca Nacional de Francia o en el palacio de Topkapi, en Estambul.

$29 \mathrm{C} 17$.

30 Pozo en el patio de la Mezquita de La Meca, de $42 \mathrm{~m}$. cuya agua ligeramente salobre tiene fama de cualidades milagrosas.

31 Muñoz Sendino, J. La escala de Mahoma. Traducción del árabe al castellano, francés y latín ordenada por Alfonso $X$ el Sabio. Madrid, 1949.

La ascensión de Mahoma a los Siete Cielos, el Mi'rach, está reproducida en la «Crónica General de España", en la Antología de Alfonso X, de SolALINDE, A. 4. ${ }^{\text {a }}$ ed. Madrid, 1960 págs. 92-95. 
Las figuras de los ángeles son diversas en cada uno de los diferentes cielos; hay ángeles con cara de hombre y cuerpo de toro, otros con cabezas de águila o de buitre, otros ángeles tienen setenta mil cabezas con setenta mil bocas en cada cabeza y otras tantas lenguas en cada boca y todas alabando a Alá.

En uno de los siete paraísos que visita Mahoma se encuentra un árbol a cuya sombra se sientan los fieles mientras se acerca una caravana de camellos guiada por ángeles cargados de dones que Alá envía a los que creen en Él.

Debajo de la tierra de los hombres hay siete infiernos, todos de fuego, cada uno con sus tormentos y fabulosos animales atormentadores, tales como escorpiones del tamaño de un mulo, serpientes inmensas con enormes dientes y multitud de bocas que tienen dieciocho mil dientes cada una destilando ponzoña, bestias espantosas que se pegan al condenado como piedras de azufre ardiendo. Por todas partes hay ríos de fuego y en sus orillas árboles llenos de gusanos cada uno segregando veneno, y árboles a cuyo pie hay dragones, escorpiones y alacranes.

Finalmente y después de cruzar los siete cielos Mahoma regresa con Gabriel, descendiendo por una escala ${ }^{32}$.

\section{Caballo}

Es uno de los animales más referidos en los Hadits y siempre con sentido positivo.

- (pág. 105, num. 60): «Existe en el Paraíso un árbol, el cual podría ser recorrido por un caballero montado sobre un caballo excelente, bien domado y rápido, durante cien años sin atraversarlo» (65-S. 55-2).

Esta tradición también quedó reflejada en el manuscrito arábigo mencionado anteriormente sobre el viaje iniciático de Mahoma al paraíso: «(..) Hay en uno de los paraísos un árbol llamado Tuba, de tronco tan grande que un jinete velocísimo no podría rodearlo en menos de cien años $(\ldots){ }^{33}$.

32 La existencia de pasajes similares en La Divina Comedia, y la concepción del viaje a los Infiernos realizado por Dante, llevó a Asín Palacios a un profundo estudio que culminó en la publicación de La Escatología musulmana en la Divina Comedia, Madrid, última edición 1984.

33 Solalinde, A. Op cit. 1960. pág. 93. 
En cuanto a impuesto:

- (pág. 121, num. 61): «El musulmán no pagará la sadaqa ${ }^{34}$ ni por su esclavo ni por su caballo».

Este impuesto de limosna sólo se aplica a ciertos animales, como camellos, vacas, cabras, ovejas y corderos, pero no al caballo. La jurisprudencia islámica, y en concreto la malikí, tienen regulaciones a este respecto.

Los hadits utilizan al caballo en una metáfora sobre la compasión:

- (pág. 144, num. 18): «Dios ha dispuesto la compasión en cien partes y ha conservado noventa y nueve para Él haciendo descender a la tierra sólo una parte. Por esta parte, sus criaturas podrán manifestar compasión, incluso el caballo levantará su pezuña del hijo de tal mujer para evitar alcanzarle $(78-19)^{35}$.

Para ejemplificar la conducta de los hombres, se utiliza en caballo con tres significados:

- (pág. 150, num. 42): “(...) Él dijo: el caballo para un hombre es una recompensa; para otro es una protección y para un tercero es un fardo:

1. El hombre para quien el caballo es una recompensa es el que lo pone en el camino del Señor que alarga la cuerda a la que se le ata en un prado o en un jardín. Todo lo que el animal alcance en la superficie limitada por esa cuerda se cuenta como una buena acción para su propietario. Si la cuerda se rompe y el animal trota un par de carreritas, las huellas de sus pasos y sus excrementos se contarán como buenas acciones de su propietario. Si ese caballo pasa cerca de un riachuelo y bebe, incluso aunque no se hubiera deseado que lo hiciera, esto también constítuye una buena acción en el activo de su dueño. El caballo, por sí mismo, es por lo tanto una recompensa.

2. El hombre que destina su caballo a su uso personal absteniéndose de todo lo ilícito y no olvidando sus deberes religiosos, temeroso de Dios, pagando el zakat y no agotando al animal, encontrará en su caballo una protección.

3. El hombre que guarda un caballo por vanidad, ostentación y aún más, para perjudicar a los musulmanes, sólo tendrá una carga (en el otro mundo)"».

34 Se refiere al zakat, impuesto o limosna ritual. A veces se usa la palabra sadaqa como sinónimo, aunque otras veces indica la limosa voluntaria no sujeta a reglamentación. PAREJA, F. Op cit. . Cap. XII. pág. 534.

35 En los hadits inmediatamente anteriores no figura ninguna referencia a la mujer de la que habla éste, pero ello no es relevante porque el sentido de la capacidad del caballo de poder sentir compasión queda manifiesto y es lo que nos interesa aquí. 
También existe un hadit de extraña significación:

- (pág. 231, num. 77). «Si existe alguna cosa de mal agüero es en la casa, la mujer y el caballo".

Quizá pueda hallarse su significado en el Corán ${ }^{36}$ que considera a la mujer y a los caballos de raza, por su belleza, seres efímeros de esta vida que no deben tentar al buen creyente.

Por último, el aspecto positivo del caballo y los beneficios Divinos parecen quedar claros en el hadit siguiente:

- (pág. 244, num. 43): «El que hace donación perpetua de un caballo en la vía de Dios por efecto de su fe y confianza en las promesas del Día del Juicio Final, verá poner a su favor en la balanza la comida, la bebida, los excrementos y la orina de ese caballo» (56-45).

\section{Camella/o}

Los hadits hablan abundantemente de los camellos debido a que es el animal que mejor caracteriza las condiciones de vida nómada. En muchísimas ocasiones tienen un sentido general de montura y debido a su abundancia no se citarán aquí.

En el hadit siguiente se tratan dos aspectos: por un lado se utiliza la orina y la leche de un rebaño de camellos como alimentación. Por otro lado, se habla del castigo impuesto por el Profeta a unos individuos que después de haber saciado su necesidad, mataron al pastor del rebaño, robaron su ganado y renegaron de su fe musulmana:

- (pág. 65, num. 15):» Un grupo de ocho oklitas querían ver al Profeta. Encontrándose mal por el viaje de Medina, le dijeron: -Oh, Enviado de Dios, procúranos leche--. - No veo otro modo, dijo Él, para vosotros que os juntéis con un rebario de camellos-. Ellos partieron y bebieron la orina y la leche de las camellas, de forma que se restablecieron y engordaron (...) pero ellos mataron al pastor, robaron el rebaño y apostataron. Envió entonces (el Profeta) gente en su búsqueda y no pasó el día sin que les apresaran. Les hizo cortar manos y pies y después ordenó que se les pincharan los ojos con un hierro al rojo vivo, perdiendo la vista. Se les llevó a continuación a la llanura de Harra y en vano demandaron de beber porque murieron» (24-68). 
Al igual que en el Corán ${ }^{37}$, los camellos son usados en las Tradiciones como metáfora que sirve de ejemplo para poder saber en qué momento del mes sagrado iniciar el ayuno:

- (pág. 118, num. 48): «Os está permitido comer y beber hasta el momento en que podáis distinguir un hilo blanco de uno negro (...). -Fui a coger una traba (de las patas) de un camello negro y otra de un camello blanco y las coloqué debajo de mi almohada. Me puse a mirarlos durante la noche sin poderlos distinguir. Por la mañana, fui en busca del Enviado de Dios y se to conté-: "Eso no se aplica nada más que a la negrura de la noche y a la blancura del día, respondió el Profeta» (30-16) ${ }^{38}$.

Como metáfora de la paternidad el camello se ha utilizado en el siguiente hadit:

- (pág. 190, num 89) : “Un hombre vino a ver al Profeta y le dijo: -Oh, Enviado de Dios, un niño negro ha nacido de mi esposa. - ¿Tienes camellos? - Sí, respondió el hombre. - ¿Y de qué color son?-Rojizos- ¿Hay alguno entre ellos que sea gris? - Sí- ¿Y como puede ser eso? Quizá sea un fenómeno de atavismo, respondió el hombre- Entonces, dijo el Profeta, puede ser que suceda lo mismo con tu hijo. (68-26)».

Cuando se adquiere un camello se pacta en ocasiones el derecho del uso de su montura hasta un lugar prefijado por comprador y vendedor. Para ilustrar la licitud de ese acuerdo se utiliza la siguiente metáfora:

- (pág. 201, num 17). «(..) Djaber nos contó que viajaba subido sobre un camello que le pertenecía y que estaba cansado. El Profeta (...) le dio un cachete al animal e hizo una invocación. El camello comenzó a caminar a una velocidad que nunca había alcanzado habiendo dicho el muy Santo: -Véndeme tu camello por una onza- Se lo vendió reservándose el derecho de montar en él hasta llegar a casa de su mujer. Cuando llegaron, llevó el camello al Profeta que le pagó el precio estipulado y se fue. El Profeta le hizo llamar y cuando había vuelto le dijo: - No tenía intención de coger tu camello, por lo tanto, guárdalo; a partir de ahora es de tu propiedad-.» (54-4).

Utilizado como una parábola en el sentido de propiedad privada:

- (pág. 206, num. 29): «Un árabe nómada vino a ver al Profeta y le interrogó acerca de los objetos que uno encuentra. - Haz conocer tu hallazgo durante un año, después cierra tu bolsa. Si alguien viene y te hace una descripción

$37 \mathrm{C} 2_{189}$

38 El ayuno tiene lugar desde el alba hasta la puesta de sol, por lo tanto durante la noche no puede distinguirse el color y pueden ingerirse los alimentos. 
exacta, dásela, si no dispón de su contenido para ti mismo- respondió. - ¿Y si se trata de un cordero perdido? - preguntó el nómada. - Será para ti, para tu hermano o para el lobo-. - - ¿Y si es un camello perdido?- preguntó el nómada. Oyendo estas palabras, el Profeta se llenó de cólera y respondió: — ¿Por qué te has de interesar por un camello? Este animal tiene pezuñas y pellejo; sabe ir a buscar agua y come de los árboles»-. (45-2).

Este hadit tiene su explicación en que según el derecho islámico y en concreto la escuela malikí, uno no pierde su derecho de propiedad y aquel que encuentra un objeto no se convierte en su propietario legal hasta pasado un tiempo y después de algunas formalidades publicitarias. El cordero perdido no puede defenderse y queda asimilado a un objeto. Sin embargo, el camello tiene pezuñas para defenderse de otras bestias y sabe encontrar el agua que guardará en su vientre; por lo tanto hay que dejar que su amo lo encuentre.

\section{Escorpión}

En el hadit que veremos a continuación se habla de la picadura de un escorpión que fue sanada por medio de la magia. Es una parábola en la que el animal es púramente simbólico pues el verdadero mensaje es que el acto del curandero es lícito En este sentido hay que destacar que no faltaban en Arabia en tiempos de Mahoma las prácticas de magia y usos supersticiosos a los que el Corán alude con frecuencia ${ }^{39}$. Mahoma admitía la existencia de un mundo de espíritus, genios ${ }^{40} \mathrm{y}$ demonios, dotados de ciencia y poder muy superior al de los hombres, pero sometidos a la voluntad de Alá y por tanto con poder directo sobre los fieles.

- (p 247, num. 109): "Abu Said relata que un grupo de compañeros del Profeta que estaban de expedición acamparon cerca de una tribu árabe. Pidieron a los árabes hospitalidad que les fue rehusada. Habiendo sido picado por un escorpión el jefe de la tribu, los árabes intentaron todos los métodos de curación sin resultado. Un árabe dijo: - ¿Y si fuésemos a ver a esa gente que ha acampado cerca de nosotros? A lo mejor alguno tiene un remedio-. Fueron a verles y les dijeron: -Oh, gentes: nuestro jefe ha sido picado por un escorpción y vanamente hemos empleado todos los sistemas de cura sin ningún resultado. ¿Alguno de vosotros tendría un remedio?Uno de los compañeros dijo: - Si, por Dios. Soy ciertamente un mago. Pero puesto que os hemos pedido hospitalidad y nos la habéis rehusado, no usaré

39 C $2_{96}, C 5_{90-93}$, Sura 113 y Sura 114.

40 En El Corán, Salomón es el rey de los genios. 
mi magia con vosotros hasta que hayáis fijado un precio-. Se convino que sería un rebaño (de corderos, ovejas,....). El compañero fue a verles (a los árabes), se puso a hacer tragar saliva al jefe recitando la primera Sura de $E$ I Corán. A medida que recitaba, le pareció al herido que se liberaba de sus ataduras y cuando terminó, se puso a andar sin el menor malestar. Los árabes pagaron el precio convenido. Uno de los compañeros dijo: -Repartamos el rebaño-. - No lo hagáis, contestó el curandero, hasta que no hayamos alcanzado al Muy Santo Enviado. Le contaremos lo sucedido y veremos lo que nos ordena-. Fueron a verle y le contaron la cosa. Él dijo: - ¿Quién dice que haya sido magia? Habéis ganado un bien. Repartidlo y reservarme una parte con vosotros»-. (76-39,3).

En opinión de Félix Pareja no era difícil islamizar los ritos mágicos haciéndolos preceder por la invocación del nombre de Alá, trasponiendo así a ideas islámicas las teorías de otros pueblos, basando las especulaciones y las fórmulas en letras, números y frases tomadas de el Corán. La tradición refería que el mismo Mahoma había admitido y empleado procedimientos mágicos en ciertos casos, como por ejemplo, contra el mal de ojo, contra la ponzoña de las serpientes y picaduras de escorpión, y en general como remedio de enfermedades. El límite entre lo permitido y lo prohibido no llegó a tener una definición precisa ${ }^{41}$.

Símbolo de la vigilia y con un sentido positivo al considerarse que es la primera voz que despierta al Profeta por la mañana, se expresa así:

- (pág. 248, num. 113): «Cuando oigas el canto de un gallo, pide una gracia a Dios porque el gallo ha visto a un ángel; pero si oyes el rebuzno de un asno, refúgiate en Dios contra el diablo porque el asno ha visto un demonio".

Este sentido de voz desagradable del asno viene también recogido en el Corán en los mismos términos ${ }^{42}$.

\section{Lagarto}

El hadit que se ha encontrado sobre este animal, tiene significación alimenticia. En ocasiones se ha utilizado para demostrar la prohibición de

41 Pareja, F. Op cit. Cap. XV. pág. 682.

$42 \mathrm{C} 31_{19}$. 
comer carne de lagarto, pero no se ha encontrado nada que permita aseverar esta afirmación; tan sólo el Profeta no los comió en ese momento:

- (pág. 133, num. 97): "Según Ibn Abbâs, su tía materna, Oumn Houfaf ofreció al Profeta mantequilla, queso blanco y lagartos. Ella hizo servir los lagartos y se comió en la mesa del Muy Santo Enviado, pero él los dejó sin tocar como si manifestara disgusto. Si el plato hubiera sido prohibido religiosamente, no se hubieran comido en la mesa del Profeta y él no habría ordenado comerlos» $(70-8,5)$.

\section{Serpiente}

Con un significado negativo, la serpiente aparece así:

- (pág. 248, num. 111): «Matad a las serpientes; matad a aquellos que tengan dos rayas y a aquellos que no tengan cola porque esos dos hacen perder la vida y abortar a la mujer encinta» (59-14).

El Corán, sin embargo, sin hacer ninguna mención ni en un sentido ni en otro se refiere a este animal exclusivamente en relación con la vara de Moisés ${ }^{43}$.

\section{LAS INTERPRETACIONES DE LA LEY}

Aceptando el mismo texto sagrado y las mismas obligaciones religiosas, los musulmanes se dividen en sectas, cada una de las cuáles interpreta el Corán de modo diferente teniendo como único nexo de unión el idioma árabe.

Las primeras y definitivas diferencias con respecto a la ortodoxia sunní surgieron en torno al ejercicio legítimo del poder (umma) en el seno de la comunidad, produciéndose desde fecha temprana movimientos secesionistas que rompieron la unidad del Islam, siendo la independencia de alAndalus la primera de una larga serie.

Al-Andalus, al margen de las tendencias que se exponen brevemente a continuación, adoptó la ortodoxia sunnita desde un primer momento y permaneció fuertemente conservador y altamente intolerante con cualquier tipo de sectarismo, siendo por este hecho quizá por lo quedó prácticamente libre y aislada de las querellas religiosas que sufrió el Este. Por ello, los movimientos religioso-políticos del Islam no se afianzaron en España como entidades organizadas.

\footnotetext{
${ }_{43} \mathrm{C} 7_{107}, \mathrm{C} 20_{20}, \mathrm{C} 26_{32}, \mathrm{C} 27_{10}, \mathrm{C} 28_{31}$.
} 
La heterodoxia del islam: la Si'ia

La si'a, (“partido» en árabe) es la primera división histórica importante que sufre el Islam y hace aparecer junto a la ortodoxia sunní que hemos visto, una línea heterodoxa y mística de comportamiento que fue radicalizándose y separándose cada vez más de ella. En realidad, no fue en su origen una cuestión de ortodoxia o heterodoxia sino un problema sucesorio. No obstante, no quiere ello decir que la Si'ia no reconozoca la Sunna sino más bien que la interpreta de una forma propia más cercana a los intereses de los descendientes de Alí.

Al igual que la Sunna, la Siila tiene diferentes escuelas y variantes, algunas más abiertas y más tolerantes que otras, que hicieron que dentro de su seno pronto surgieran divergencias de muy complicada explicación. Tres son sus tendencias principales: duodecimanismo, ismailismo y zahirismo. Si bien es cierto que la Si'ia existió en la España musulmana lo fue con carácter minoritario y nunca formó parte del patrimonio jurídico de las tierras de al-Andalus sino en determinados medios sociales más o menos sublevados contra el poder central o entre círculos intelectuales muy alejados del pensamiento común. A estas tres tendencias deben añadirse el jarichismo, grupo islámico puritano nacido en el año 657 de una escisión entre los partidarios de Alí con los omeyas y la Mutaliza, grupo de musulmanes que no quisieron participar en la disputa dinástica entre los partidarios del cuarto y último califa, Alí, y el primero de los omeyas, Muawiya, permaneciendo neutrales. Esta doctrina ha sido considerada parte de la comunidad sunni si bien separada dentro de ella.

Las Tradiciones no suelen recibir entre los síes el nombre de hadit sino el de ajbar (noticias), teniendo la misma concepción de trasmisión oral. Gran parte de las tradiciones siíes tienen el mismo contenido que las sunníes de las que se diferencian por los isnad, es decir, la serie o cadena de transmisión de la tradición.

Los hermanos de la pureza (Rasail ljwan al-safa wa jillan al-wafa) ${ }^{44}$

El interés por la clasificación de los saberes en el Islam árabe comenzó a finales del siglo ॥ de la Hégira con Ibn Hayyan (m. 815) aunque sería en

44 El desconocimiento de la lengua árabe que tan evidente se hace en este trabajo, ha impedido manejar la fuente original de los Rasail, lo que constituye un handicap que incide negativamente en la investigación que se ha pretendido llevar a cabo en relación con el abundante tratamiento que los Hermanos de la Pureza otorgan a los animales. Para todo lo relacionado con los Rasail se ha acudido a Puerta VILCHEZ, J.M. Historia del Pensamiento estético árabe. Al-Andalus 
los siglos siguientes y sobre todo en el V de la Hégira cuando florecería la preocupación taxonómica por las ciencias como fruto del desarrollo y diversificación del pensamiento islámico. Entre los pensadores más destacados que dejaron obras específicas están, entre otros, Abu Nasr al-Farabí «El segundo Maestro» y los «Hermanos de la Pureza», comunidad ismailí que compuso una célebre Enciclopedia en al año 983, conocida desde muy temprano en al-Andalus y manejada por los sabios andalusíes ${ }^{45}$.

Las referencias a animales en esta Enciclopedia son abundantes y debe incluirse este aspecto dentro del concepto de proporción ideal como base de toda composición y baremo de perfección de una obra. Una relación armónica adecuada produce belleza y esta armonía debe producirse también en las figuras de seres vivos: "los miembros de las imágenes y sus articulaciones son de diferentes figuras y medidas pero cuando sus medidas se relacionan proporcionalmente, la forma resultante es correcta, veraz y admisible». Este principio lo hacen extensible a las obras de la naturaleza que consideran son la combinación de sabores, aromas, minerales, diversos tipos de plantas, los animales y el cuerpo humano, siendo éste ultimo un modelo de armonía.

Este concepto de armonía que bien podría ser derivación griega tiene su reflejo en el Corán:

- C $40_{64}, 643$ y $95_{4}$ : «Hemos creado al hombre dándole la mejor complexión».

- C $82_{8}$ : «Te ha creado (Dios), dado forma y disposición armoniosa y te ha formado con la forma que ha querido".

Partiendo de esta concepción, los Hermanos de la Pureza hacen una descripción del cuerpo humano y también del de los animales, observando su armonía general como modelo artístico: «las especies animales de este mundo son espectros e imitaciones de las ideas y seres del mundo astral y de la inmensidad celestial, lo mismo que las pinturas e imágenes de las paredes y techos son espectros e imitaciones de las imágenes de los animales» ${ }^{46}$.

\footnotetext{
y la estética árabe clásica. Ed. Akal, Madrid, 1997. págs, 183-207 y a Cruz Hernández, M. Historia del pensamiento islámico. Ed. Alianza Universidad, Madrid, 1996, Vol I. págs. 60-82. Existe una edicición en italiano de Bausani, A. L'enciclopedia de Fratelli della Puritá, Nápoles, 1978, a la que no se ha podido tener acceso.

45 Según Joaquín Lomba, la Enciclopedia entró en al-Andalus por Zaragoza en el año 1065, si bien circulaban con anterioridad algunos resúmenes. LOMBA FUENTES, J. La filosofía islámica en Zaragoza. Diputación General de Aragón. Zaragoza, 1987. pág. 63.

${ }_{46}$ Puerta VILcheZ, J. Historia del pensamiento estético árabe. Al-Andalus y la estética árabe clásica. Ed. Akal, Madrid, 1997. pág. 199.
} 


\section{LAS ESCUELAS JURIDICAS}

El punto de partida de la jurisprudencia islámica Félix Pareja lo coloca ${ }^{47}$ hacia el final del califato omeya de Damasco, cuando nace el ilm-al-hadit y cuando en Iraq y Siria comienzan a esbozarse tendencias jurídicas muy condicionadas por circunstancias de aislamientos locales que más tarde tomarán cuerpo en las respectivas escuelas de derecho.

La Sunna reconoce cuatro escuelas válidas que quedaron prácticamente constituidas, reconocidas y aceptadas, durante los siglos II y III de la Hégira, es decir los siglos VIII y Ix de la edad cristiana: Hanafitas, Malikitas, Safiitas y Hanbalitas, que se diferencian por ligeras variaciones de interpretación, principalmente de carácter jurídico. El hecho de que se admita a las cuatro escuelas por igualmente ortodoxas hace ya comprender que las diferencias entre ellas no pueden ser sustanciales. Cuando la doctrina de las cuatro coincide sobre una materia determinada es cuando ese acuerdo constituye el consenso y es obligatorio para todos. Cuando difieren, las normas particulares de cada una obligan sólo a los adeptos. Todo musulmán debe pertenecer a una de ellas y cumplir con sus preceptos.

Las escuelas jurídicas, excepto el hanbalismo, no adoptaron criterios teológicos pero siempre existió una profunda afinidad de reflexión sobre la Ley y cada escuela difundió su doctrina predominantemente en algún sector del mundo islámico, aunque nunca con exclusividad. Los safidíes predominaron en Arabia, Siria y Egipto en donde compartieron terreno con los malikíes, que tenían mayoría de seguidores en el Magreb y en la España musulmana. El hanefismo se extendió en Irán y compartió el espacio iraquí con el hanbalismo.

Las escuelas jurídicas han intentado, de una forma completamente empírica, poner un final a la incertidumbre que existe sobre el primer periodo del Islam y en lo que a animales se se refiere, trataron de confeccionar listas de ellos especialmente destinadas a elucidar cuando su consumo es legal - halal-, prohibido - haram -, o censurable - makruh, sin haber llegado en absoluto a un acuerdo. A este respecto el Hayat al-Hayawan de Damiri ${ }^{48}$, utilizado con precaución, es el manual más útil sobre este asunto, ya que el autor indica la clasificación legal de cada especie de acuerdo con las diferentes escuelas y es obra rica en informaciones folclóricas de

47 PAREJA, F. op. cit. pág. 514.

48 Hasta el momento no hay traducción del árabe, pero existe una obra en francés que indica las fuentes en las que se basó al-Damiri. SOMOGYI, Joseph de, Index des sources de la Hayat alHayawan de al-Damiri, Ed. Imprimerie Metome. Paris, 1928. 
cada animal que sale en los hadits, en la ley canónica y en las supersticiones populares.

\section{LA FORMACIÓN DEL DERECHO ISLÁMICO EN AL-ANDALUS}

En este capítulo se tratará de manera especial la escuela malikí pues no en vano fue la que entró en España con enorme fuerza y se impuso como doctrina oficial en al-Andalus, en el año 199H/815 d.C, siendo las demás minoritarias o al borde de la heterodoxia.

Abu Muhammad Abd Allah Ibn Abi Zayd, Ilamado Al-Qayrawani por residir la mayor parte de su vida en Qayrawan, Túnez, era alfaquí, es decir, experto en derecho islámico; nacido el año $310 \mathrm{H} / 923$ d.C. recogió la jurisprudencia que regía en la escuela malikí de al-Andalus en Risala fi-l-figh (Compendio de derecho islámico). Su Risala ha sido traducido por primera vez al castellano por Jesús Riosalido, que lo ha obtenido a través de una abundante bibliografía árabe que figura al final de su Compendio ${ }^{49}$ en donde se han basado todas las conclusiones que figuran en este capítulo.

Ante las insuficiencias en las regulaciones coránicas y para poder llegar a un acuerdo en el aspecto de la legalidad de los animales, los doctores islámicos aplicaron criterios generales, en los que tampoco fueron unánimes, basándose en el Corán y en las Tradiciones; el análisis, escuela a escuela, de las diferentes consideraciones que en materia de animales acercan o alejan a cada una de ellas es tema harto extenso e inabarcable por los complejos problemas jurídicos que plantea el Derecho musulmán ortodoxo.

Para poder presentar este intrincado tema por completo sería necesario realizar una lista de todos los animales que existen e indicar para cada uno de ellos el criterio adoptado por cada escuela. Ello plantea graves dificultades debido, principalmente, a que ni siquiera existen regulaciones específicas para cada uno de los animales del planeta y es muy escasa la bibliografía existente. Además, la complejidad del derecho islámico requeriría un estudio en profundidad en materia jurídica realizado por especialistas ya que mínimas diferencias de detalle nos conducen a un intrincado laberinto teológico filosófico del que es difícil salir.

No obstante lo anterior, las páginas que siguen puede dar una idea muy cercana de los intensos y ásperos debates a que debieron someterse

49 Riosalido, J. Compendio de derecho islámico (Risala-fi-l-Figh) de lbn Abi Zayd alQayrawani. Ed. Trota, Madrid, 1993. 
las diferentes escuelas y lo que piensa cada una de ellas en materia de animales. Una vez más, nos demuestra la complicada madeja de regulaciones y excepciones que separan a los expertos y el enorme conjunto de ideas, teorías y sistematizaciones que tiene el Islam en su seno.

Ante todo debe recalcarse que los Si'ies no difieren radicalmente de los Sunnitas y aunque no se ponen de acuerdo en algunos puntos de detalle, basan sus decisiones en criterios idénticos.

\section{Impuesto sobre animales}

La distinción básica del Derecho tributario islámico en cuanto a impuestos se refiere, es el zakat que afecta a las personas y directamente a todos los musulmanes y se considera como un honor, existiendo otro impuesto que se conoce con el nombre de dimma que se recauda a los no musulmanes sometidos y es una forma de capitación ${ }^{50}$.

El zakat sobre camellos, vacas, ovejas y corderos era una obligación de Derecho divino y variaba dependiendo del número que de ellos se poseyera, por ejemplo, a partir de cinco y hasta el límite de nueve, se pagaba una cabeza de ovino de entre uno y dos años, para ir aumentando esa cantidad progresivarnente. En el caso de la España musulmana en donde el camello no es animal común, este impuesto afectó a otro tipo de animales como asnos, mulas etc... Dos excepciones existían en el pago del zakat: no se tributaba por poseer un esclavo o un caballo.

Los malikitas, safiitas y hanbalitas consideraban que este impuesto debía ser pagado por todo musulmán que pudiera sostenerse a sí mismo y a su familia; los hanefitas exigían, además, que pudiera atender a su vivienda, a su esclavo, a su caballo y a sus armas, por un valor de doscientos dirhams.

\section{Sacrificios y víctimas}

El sacrificio en el Islam es una tradición obligatoria para todo aquel que pueda llevar a cabo la Peregrinación a La Meca y se basa en varios versos de El Corán ${ }^{51}$. Puede realizarse por corte de yugular — dabh-o por

\footnotetext{
50 Para ver como afecta el zakat y sus diferencias con la dimma, RIOSALIDO, J. Compendio de derecho islámico, págs. 177-180.

51 C $2_{196}, \mathrm{C} 6_{161+162}, \mathrm{C} 22_{26-28,2230,34-37,78^{\circ}}$
} 
incisión de cuchillo - nahr - en el primer día de la Fiesta del Sacrificio ${ }^{52}$, por la mañana, y debe terminar con la puesta del sol del día tercero. Aunque estas dos voces tiene significación parecida - sacrificio ritual, inmolación- dabh es utilizado en cuanto al sacrificio de animales pequeños mientras que nahr lo es para animales más grandes y de cuello largo.

El sacrificio denominado dabh consiste en seccionar la garganta y las venas yugulares a la vez, sin que sea válido seccionar menos que lo señalado. Si se levanta la mano después de haber empezado a cortar al animal y se sigue para terminar, la víctima no podrá ser consumida, pero si se excede hasta el punto de cortar la cabeza de la víctima el animal puede comerse. El sacrificio por el cogote de la ofrenda impide que ésta pueda ser consumida.

Las diferentes escuelas no se ponen de acuerdo sobre la forma de sacrificar a determinadas víctimas, aunque en general se estima preferible sacrificar a las vacas y ovejas por dabh y al camello por nahr existiendo diferentes opiniones en cuanto a mínimas cuestiones de detalle, por ejemplo, el mínimo permitido para sacrificar es una cabeza de ganado ovino de un año - tani- aunque hay ligeras discrepancias en este sentido. Así, unos consideran que la víctima debe tener ocho meses, otros diez meses, otros prefieren que sea una cabeza de caprino de más de un año, etc...

Para el sacrificio, se prefiere entre los ovinos a los machos enteros; en su defecto a los machos castrados y en defecto de estos últimos a las hembras. Éstas son preferibles a los cabritos y a las cabras. Los machos cabríos enteros se prefieren a sus hembras mientras que la hembra de éste es preferida al camello y a la vaca.

No puede venderse la carne, la piel, la grasa, los tendones, ni ninguna otra cosa de las víctimas que se hayan ofrecido en la Peregrinación o por un recién nacido, pero sí comerlas, aunque se considera mejor entregarlas como limosna.

\section{Alimentación y prohibiciones alimentarias}

Este capítulo presenta gran interés desde el punto de vista teológico pues se trata, en general, de las obligaciones del creyente para con Dios en cuanto a tradiciones y prácticas que entran de lleno dentro del ámbito del comportamiento ritual y social de cada persona. Meca.

${ }^{52}$ La Fiesta de los Sacrificios tiene lugar el décimo día del mes de la Peregrinación a La 
Veíamos que Dios había prohibido comer la carne de animales muertos, la sangre y la carne de cerdo, al igual que la carne sacrificada a una persona no divina o a un dios que no sea Alá ${ }^{53}$. Asímismo está prohibido el consumo de un animal estrangulado por un cordel o similar, muerto a palos o de cualquier otro modo violento, despeñado, corneado o comido por fieras, si ha sido herido tan gravemente que no pueda vivir con sus heridas, no podrá comerse a menos que haya necesidad absoluta de consumirlo.

Los malikitas, safiitas y algunos hanafitas consideran que no hay inconveniente, en caso de necesidad para subsistir, en comer animales muertos pero con la obligación de prescindir de su carne en cuanto la necesidad haya quedado cubierta.

En cuanto al cerdo, se considera que todo cuanto produce este animal está prohibido estimando elCorán ${ }^{54}$ su carne como malsana para el consumo humano. Observando atentamente esos versos se aprecia la excepción a la regla cuando se permite a los musulmanes la libertad de infringir este precepto en caso de necesidad dejando la decisión al juicio de la conciencia individual.

Por lo tanto, vemos que las Tradiciones del Profeta y la jurisprudencia islámica conceden la posibilidad de consumir animales prohibidos en caso de absoluta necesidad natural y biológica, aunque en general son muy estrictos e imponen prohibiciones sobre especies de las que no se ha dicho nada en el Corán pero sin restaurar las prácticas pre-islámicas, como por ejemplo, aquellas que realizaban los árabes primitivos cuando iban muriendo de sed por el desierto, y tenían que resignarse a veces a sacrificar un camello y beber su sangre. No obstante, de esas prácticas se poseen escasos datos hasta el momento.

Caso especial es el de los peces escatófagos, es decir, encontrados dentro del estómago de otro pez y, sobre todo, el tafi, pez muerto que flota en el agua, que es legal únicamente para los Malikitas y los Safiitas, aunque los Hanefitas lo permiten si ha sido muerto por accidente y no por muerte natural. Ello lleva a la discusión entre las diferentes escuelas de si la muerte por frío o calor se considera como natural.

En general, los pájaros que no tienen garras están permitidos, pero algunos de ellos son objeto de discusión y reciben diferentes clasificaciones

\footnotetext{
53 El rechazo a consumir este tipo de carne, así como la sangre, no es exclusivo del Islam sino que se extiende, junto con el judaísmo a determinadas confesiones cristianas de Oriente Medio, como la iglesia copta ortodoxa.

54 C $2_{173}, 5_{4 ;} 6_{145} ; 16_{115}$.
} 
de acuerdo con las diferentes escuelas; este es el caso del loro y del buho que ha llevado a profundas discusiones de clasificación sin que haya podido lograrse un acuerdo. Los Síies incluyen entre la carne que está prohibida o censurada la de algunos pájaros particulares, como la alondra y la de dos nuevas categorías: pájaros que revolotean más que vuelan y pájaros que carecen de estómago y otros órganos.

Todas las escuelas consideran al gato, al lobo y al cocodrilo como prohibidos; el zorro es generalmente considerado legal asi como la hiena, mientras que el chacal y el gato salvaje son objeto de desacuerdo. Asimismo, la clasificación del elefante plantea disputas, puesto que aunque es herbívoro, tiene colmillos como medios de defensa.

Las langostas que constituyen una forma suplementaria de alimento para los beduinos, no están prohibidas por ninguna escuela, ni siquiera cuando se encuentran muertas ${ }^{55}$. No obstante, algunos insisten en que deben ser matadas y sus cabezas cortadas. Los si'itas, en contra de esta opinión citan a Alí, a quien se le atribuye haber dicho «comerlo todo", cuando se le mostró un montón de langostas algunas de las cuales estaban ya muertas ${ }^{56}$.

Los reptiles son generalmente considerados ilegales o censurables, excepto entre los Malikitas que simplemente aplican el criterio de nocividad y autorizan su ingestión, incluso serpientes venenosas si la parte del veneno ha sido cortada

Estas consideraciones generales dejan abierta la puerta para hallar nuevos argumentos, especialmente en el caso de los animales que son difíciles de clasificar. Esto es especialmente verdadero para el hasharat alard (a veces khashash), término que abarca de una forma variable, los pequeños animales que viven en el suelo y que están en general prohibidos o censurados incluyendo los escorpiones, toda clase de insectos y los gusanos. Respecto a estos últimos existe mucho desacuerdo debido a su dificultad de no ser ingeridos accidentalmente con otras comidas. Algunas escuelas hacen esfuerzos para distinguir aquellos que han sido engendrados por la comida misma de aquellos otros que no lo han sido, aquellos que están vivos o muertos, aquellos que tienen ruh -alma-o no, etc. Asimismo, la jirafa es discutida y, finalmente, el mono, se considera prohibido por todas las escuelas excepto por los malikitas.

55 Este es, junto con el tafi, el pez muerto que flota en el agua, el único caso de legalidad de consumo de animal muerto.

56 PELLAT, Ch. «Hayawan» en Enciclopaedia del /slam. III. pág. 307, que lo ha tomado de alMarhinani, Hidaya, mr. Paris ar. 6773 , fol. 248 v. 
Entre Siitas y Sunnitas aparecen divergencias en cuanto a la ingestión de carne de liebre. A este respecto Ibn Battuta relata ${ }^{57}$ que para los hanefitas de Sinope (Sanub, en Anatolia) la mejor forma de asegurarse a sí mismos de que un viajero y sus acompañantes eran adictos al Sunnismo o no, era ofrecerles una liebre, cosa que hicieron con él. Ibn Battuta dijo ser malikí, es decir sunnita, degolló a la liebre, la cocinó y la comieron. De esa forma trataban de saber que no eran si'itas pues éstos no consumen liebre jamás, siguiendo la norma judía ${ }^{58}$.

\section{Otras regulaciones}

El derecho islámico deja pocos aspectos sin regular. Así por ejemplo, en cuanto a la caza, no existen diferencias apreciables entre las escuelas, estando prohibida la misma siempre que se realice por diversión. Las piezas que mate el perro o el halcón entrenados para ello y lanzados contra la presa, es lícito comerlas, así como lo que las aves de presa hayan herido de muerte, pero si se llega a tiempo antes de que el animal muera, este debe inmolarse previamente a ser ingerido ocurriendo lo mismo para todo aquello que se cace con flechas o con lanza. Si la pieza escapa y se la vuelve a encontrar otra vez muerta por la misma flecha, puede comerse si no ha transcurrido una noche.

Las penas por delitos de sangre y otros castigos quedan reguladas en virtud del talión que se convierte en fundamento del Derecho penal islámico cuando estipula: «no se mata a nadie por nadie sino en virtud de prueba definitiva, de confesión o de juramento". La alternativa común a la ley del talión suele ser el cobro de una compensación económica o "precio de la sangre" (diyya). Esto es así para los malikitas, hanbalitas y safiitas que permiten sustituir el talión con la diyya a menos que haya mediado perdón, en cuyo caso nada se debe. Sólo los hanefitas consideran obligatorio el talión en caso de asesinato.

Las diyyas son diferentes para cada caso concreto, siendo, en la práctica totalidad de los casos, compensaciones económicas en modo de camellos.

Los delitos sexuales tienen diferentes castigos en el derecho islámico. En el caso concreto del bestialismo conlleva una pena correccional para tres de los grandes Imames, malikitas, hanefitas y hanbalitas. Sin embargo,

57 Ibn Battuta A través del Islam. Ed. Alianza Universidad. 13. a reimp. Madrid, 1977. pág. 253.

58 Levítico $11_{6}$ 
los safiitas condenan a muerte a quienes realicen estas prácticas. En cuanto al animal, los malikitas consideran que la bestia no ha de ser molestada, hanefitas $y$ safiitas dicen que ha de ser sacrificada si su carne puede comerse, opinando los hanbalitas de la misma forma incluso si su carne no es comestible.

En general, a los musulmanes se les aconseja tratar bien a los animales, y particularmente a sus cabalgaduras, porque ellos tendrán que dar cuenta en el otro mundo de cualquier crueldad que les hayan infligido en éste ${ }^{59}$. A este respecto pueden recordarse dos hadiths relacionados con animales, que tienen un sentido opuesto, es decir, uno que castiga y otro que perdona:

- «Una mujer había martirizado a una gata: ésta enfermó y murió de hambre. Por esto ella fue al Infierno. Salvo error, (Dios o el Guardián del Infierno) le dijo: «Tu no la has alimentado, ni dado de beber, por lo tanto tu la has enfermado y no la has dejado ir libremente para que se alimentara de los pequeños animalillos salvajes".

- «El Profeta dijo: Un hombre que caminaba fue torturado por la sed. Descendió a un pozo y bebió. A medida que iba saliendo vio a un perro jadeante que comía tierra de tanta sed que tenía. El hombre se dijo: He aquí uno que está tan afectado como lo he estado yo mismo. Llenó entonces su cantimplora, la cogió entre los dientes, salió del pozo y dio de beber al perro. Dios le recompensó por su acto y le perdonó sus faltas. (...) Dijo: Oh enviado: ¿es que tendremos una recompensa celeste por hacer bien a los animales? Él dijo: Por hacer bien a todo ser viviente habrá una retribución. Aquel que se arrepienta de una donación es como el perro que vuelve a su vómito. Nada es peor a nuestros ojos".

Finalmente, cabe destacar que el único jurisconsulto clásico que no ha considerado inmundo al perro es Malik; por ello, cuando se trata de la piel de los animales purificada por el curtido, hanbalitas y safiitas consideran inmundas las pieles tanto del cerdo como las del perro; por el contrario malikitas y hanefitas consideran que la única que no puede purificarse es la piel del cerdo.

\section{EL PROBLEMA DE LA REPRESENTACIÓN FIGURATIVA}

Uno de los aspectos definitorios de la ley islámica en cuanto a los animales es la creencia en la prohibición de la representación o figuración de seres vivos. En este capítulo se abordará este aspecto exclusivamente bajo el

59 Para comportamiento con los animales, ver BousouET, G.H. Des animaux et de leur traitment selon le Judaisme, le Christianisme et I'Islam, St. Is. IX, 1958. 
punto de vista de su fundamento jurídico y religioso, entrando apenas de pasada en el hecho artístico al ser difícil en ocasiones separar los conceptos, pues el pensamiento estético árabe es también su pensamiento religioso.

Casi todas las obras consagradas al estudio del arte en el Islam han dedicado una introducción a clarificar el tema de la figuración ${ }^{60}$ haciendo especial hincapié en especificar que la prohibición no se da en el Corán sino en la Sunna y ello en un contexto que significa prohibición de la representación de seres vivos en cuanto que pueda suponer una adoración a un ídolo o a otro dios. Ello es lo que explica que no se encuentre este tipo de representaciones en la mezquita, lugar de abstracción y concentración espiritual por excelencia.

La identificación de las imágenes con la vida real, que es lo que está en la base de las actitudes contra la representación figurativa, no es exclusiva de la cultura islámica sino que se trata de un fenómeno de arraigo prácticamente universal que se extiende desde la Antigüedad hasta la actualidad en diferentes culturas. Es el caso, por ejemplo, de los modeladores de figuritas de arcilla que veíamos también en el Corán ${ }^{61}$. El griego Prometeo modelaba figuras humanas de arcilla a las que no podía dar vida. Cuando consiguió, con ayuda de Minerva, robar el fuego divino del cielo, pudo dar alma a sus criaturas ${ }^{62}$, pero Prometeo fue castigado $y$ amarrado a las rocas del Cáucaso y condenado a que un águila le arrancase perpetuamente a pedazos el hígado que se regeneraba constantemente. O Hefesto, el dios del fuego, que fue castigado por los dioses con la cojera por crear figuras humanas dotadas de movimiento, y también creador de Pandora modelando su cuerpo en barro. O Epimeteo, hermano «torpe» de Prometeo que modeló una figura humana de arcilla y por esta imitación Júpiter lo convirtió en mono ${ }^{63}$, etc...

60 Entre otros, véase ARnOL, T. Painting in Islam, ed. N. York, 1965. SIJELMASSI Y KHATIBI The splendor of Islamic calligraphy, Londres, 1976, AZIZA, M.L'image et l'Islam, Paris 1978. CRESWELL, K.A.C. «The Lawfulness of Painting in Early Islam» en Ars islamcia, XI-XII, pág. 166. GRABAR, O. "Actitudes islámicas ante las artes" en La formación del arte islámico. Madrid, Ed. Cátedra, 1979. pág. 93. MASSIGNON, L. «Los métodos de realización artística de los pueblos del Islam» en Revista de Occidente, $\mathrm{n} .^{\circ}$ 38. 1932, pág. 257-261. PUERTA VILCHEZ, M. Historia del pensamiento estético árabe. Al-Andalus y la estética árabe clásica. Ed. Akal, Madrid, 1997. En esta obra se destaca la opinión de autores árabes en este sentido, como Aff Bahnasi o Bis Faris. págs. 88-96. MARÇAIS, G, «La question des images dans l'art musulman» en Bizantion, VIl, 1932. págs. 161-183.

$61 \mathrm{C} 3_{49}, \mathrm{C} 5{ }_{110^{\circ}}$

62 Según la creencia griega el hombre estaba compuesto de tierra y fuego (Platón: Protágoras, $320 \mathrm{D})$. Para los musulmanes el hombre está creado de arcilla, y los ángeles de

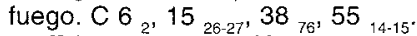

${ }^{63}$ La transformación en mono también se da en las versiones talmúdicas de la historia de la Torre de Babel, en la que sus constructores fueron convertidos en monos (Sanedrin 109 a) así como en El Corán, cuando se refiere a los judíos convertidos en monos (C $2_{65}, \mathrm{C}_{60}, \mathrm{C} 7_{166}$ ). 
Es difícil precisar a qué se debe exactamente el fetichismo hacia las imágenes que aún hoy no ha desaparecido del todo. Según Ernst Kris y Otto Kurz ${ }^{64}$ entre las hipótesis más plausibles está la que remite a los particulares procesos del pensamiento mágico de los pueblos primitivos donde no se establece una separación clara entre los objetos reales y su representación, lo que justificaría el intento de actuar sobre la realidad a partir de figuraciones y símbolos.

Las manifestaciones más contundentes y explícitas en contra de la figuración se contienen en los Hadits o Tradiciones del Profeta, la Sunna, en donde aparecen numerosas historias reprobadoras. Para la Sunna, Dios es el único Musawwir, es decir, Creador, y por lo tanto la naturaleza humana es incapaz de crear imágenes con espíritu vital y el intento de hacerlo lleva inexorablemente al fracaso y al más grave de los pecados, el asociacionismo.

En los los hadits analizados se ha hallado un muestrario muy significativo de las Tradiciones que se han transmitido comunmente en contra de las imágenes y la figuración; veamos tres de entre algunos de ellos:

- El propio ángel Yibril le dice al Profeta que «ellos, los ángeles, no entrarán en la casa en la que haya un perro o imágenes».

- "Los que serán más fuertemente castigados por Dios el Día de la Resurrección serán los creadores de imágenes".

- «(...) El que dibuja la figura de un ser animado será torturado y después obligado a darle el hálito de la vida, pero no lo conseguirá (...)».

A pesar de la severa prescripcion de los Hadits sobre las representaciones de imágenes, debe apuntarse que ciertas figuras de animales fueron utilizadas por sus cualidades ornamentales y por sus diferentes connotaciones, a menudo asociadas con la glorificación del poder real ya en tiempos de los omeyas, como es el caso del león. Así, por ejemplo, ciertos elementos de los bestiarios fueron incorporados a la esculturas esculpidas, como las que existen en la fachada del palacio de Mshatta, o las bóvedas pintadas en Kusayr Amra, o el principal mosaico del castillo de Khirbat-alMadfiar que tiene como tema dos gacelas enfrentadas, pastando, y un león que ataca a una de ellas, o los estucos de decoración con frisos de animales en las casas de Samarra o los botes de marfil realizados en la España musulmana en los siglos iv al $\mathrm{x}$ o las fuentes que decoraban los palacios andalusies, etc. etc... ${ }^{65}$. 
Por todo ello cabe concluir que en el caso del Islam fueron las restricciones religiosas las que impusieron la prohibición de todas las representaciones de cuerpos vivos, hecho que explica su total ausencia de los edificios religiosos. La peculiaridad de esta actidud estriba en que los musulmanes interpretaron el potencial poder mágico de las imáganes como un intento de suplantar al único Creador. Pero si las obras de arte están realizadas por un artista que es quien las ha realizado según su deseo, quiere eso decir que él es su creador, lo que choca frontalmente con la idea de unicidad de Dios, por lo que podría decirse que las prohibiciones o recomendaciones han llegado a través de la aplicación estricta de la teología. Ahora bien, si Dios es el Único Creador, conocedor y responsable último de los actos de los hombres que Él ha creado ¿no es Él también el que crea esas imágenes a través del hombre?

Quizá esta reflexión no esté tan alejada del pensamiento heterodoxo islámico, pues si tomanos como ejemplo el pensamiento siita de Los Hermanos de la Pureza ${ }^{66}$ en un apartado específico dedicado a las «artes y oficios» se aprecia como los Rasail integran el trabajo humano en una jerarquía que abarca todos los elementos de la creación: Dios crea el alma universal, ésta crea la Naturaleza, ésta crea al ser humano y éste, finalmente, realiza objetos que son su propia creación, como esculturas, pinturas, etc... siendo por tanto que el objeto producto del artesano es un objeto integrado en la cadena de la creación que depende, en última instancia, de Dios.

No obstante lo anterior, la duda y la excepción permanece: existe un mihrab en una mezquita de Mosul ${ }^{67}$ datado en el siglo XII que presenta figuras humanas a lo largo de toda su arcadura. ¿Por qué se produjo este hecho? ¿Es un caso aislado o existen otros ejemplos? Dado que el contenido de este artículo se centra en la presencia de los animales en los textos sagrados del Islam no se abordará esta cuestión aunque quizá sea éste un tema lo suficientemente interesante como para que sea objeto de un estudio más específico.

Si el planteamiento final es conocer a qué lleva la aplicación estricta de la teología podría sernos de ayuda el pensamiento de Ortega y Gasset expresado en el prólogo de El Collar de la Paloma, de Ibn Hazm ${ }^{68}$ : «la

66 Puerta VILChez, M. Op. cit. Para lo relacionado con los Hermanos de la Pueza (Rasail jjwan al-safa wa jillan al-wafa) págs. 183-207.

67 Rice, T. Islamic Art. Artes Gráficas Toledo, 1984. Fig. 95, pág. 98.

68 IBN HAZM. El Collar de la Paloma. Trad. de Emilio García Gómez, prologado por José Ortega y Gasset. Ed. Alianza, Madrid $1983^{3}$ págs. 9-26. 
diferencia entre cristianismo e Islam es que los árabes recibieron la Antigüedad en su aspecto de Imperio Romano de Oriente y los europeos en forma de Imperio Romano de Occidente. Ello trajo consigo que los árabes pudieran tener muy pronto a Aristóteles mientras que el cristianimso suscitador del Islam fue el nestoriano y el monofisita, dos perfiles arcaicos de la fe cristiana. En los estadios siguientes, la recepción del legado del mundo antiguo fue tomando poco a poco caracteres más divergentes, hasta que en el siglo XIII cesa entre los árabes, cuya civilización queda reseca y petrificada a fuerza de Corán». Quizá podría añadirse a esta aseveración de Ortega que no sólo a fuerza de Corán sino también a fuerza de la variada y complicada interpretación que del mismo se hizo en los hadits.

\section{A MODO DE CONCLUSIÓN}

El Islam es un mundo fundamentado en la fe religiosa. Todo está dentro de esa fe sin que nada se entienda fuera de ella. También ese es el caso de los animales a los que los textos sagrados del Islam, Corán, Sunna y Sari'ah, hacen frecuentes referencias. La obligatoriedad que implican esos tres textos hace que el animal no salga de la esfera de lo sagrado.

Todos los animales que figuran en el Libro Sagrado eran ya conocidos por La Biblia aunque el Islam no puede prescindir de su herencia fundamental: la beduina, indisociablemente unida a determinadas especies de fauna. Por ejemplo, el camello, animal por excelencia del desierto, o el caballo, criatura emblemática para los árabes pero que en La Biblia no tiene buena simbología al asociársele siempre con los invasores del pueblo escogido. Ello parecería indicar que el mundo árabe comenzó a tener sus animales favoritos - camello y caballo-, claves para comprender la expansión y conquista de! Islam.

Como no podría ser de otro modo, la Sunna es una confirmación del Corán pero tiene la particularidad de que algún animal tan sólo aparece en las Tradiciones y no en el Libro Sagrado; este es el caso de un animal paradigmático para los árabes, el alado y blanco caballo Buraq, sublimador de su especie, que fue la montura de Mahoma en su viaje iniciático. Otros animales, como el perro, pese a revalidar su simbología negativa, no tiene ese carácter en todas las Tradiciones. Baste recordar el caso del hermosísimo hadit sobre el perro sediento y el hombre compasivo que al darle de beber se aseguró la gracia divina.

A pesar de la importancia que la Sunna tiene en el mundo islámico, la bibliografía disponible traducida del árabe para analizar los hadits es muy 
escasa, lo que hace pensar que este tema no ha gozado todavía de la suficiente atención por parte de los estudiosos del Islam.

El tercer texto, la Sariah queda expuesto brevemente en los capítulos dedicados a las interpretaciones de la ley. En el caso de la heterodoxia siita de los Hermanos de la Pureza en cuyo ideario los animales aparecen armónicamente hermanados en la naturaleza y el hombre, también nos hemos topado con la dificultad de la escasa bibliografía traducida, por lo que se mantiene lo expresado al respecto en el párrafo anterior. Algo más extensamente se han abordado las escuelas jurídicas y la formación del derecho islámico en al-Andalus en donde quedan expuestas sus respectivas opiniones, en ocasiones mínimamente divergentes, que han permitido llegar a conclusiones sobre sus diferentes posturas. Así, ha podido confirmarse que la escuela malikí, la más influyente de la España musulmana, fue la más transigente en sus consideraciones sobre los animales; por ejemplo, es la única escuela que no considera impuro al perro. De este aspecto parece deducirse un sustrato cultural de gran interés como es la influencia del medio, de los países conquistados, de las culturas que impregnaron la vida cotidiana del Islam y que merecería más atención en el futuro.

Hasta el momento son pocos los textos árabes clásicos investigados por los expertos en los que conste expresamente el rechazo a los comentarios restrictivos frente a la figuración artística, aunque existen algunos que arrojan claridad al respecto. Al no existir traducciones de estos textos $y$ al no poder acometerse en este trabajo el estudio de las fuentes originales por el desconocimiento de la lengua árabe, se ha recurrido a lo expuesto por Puerta Vilchez en el Historia del pensamiento estético árabe. Al-Andalus y la estética árabe clásica ${ }^{69}$ que ha analizado los textos del historiador Bisr Faris que escribió Sirr al-zajrafa al-islamiyya (Essai sur l'esprit de la decoration islamique) ${ }^{70}$. Bisr Faris demostró en este trabajo que los grandes sabios de los primeros siglos del Islam y expertos en textos sagrados se oponían claramente a la existencia de una pohibicion canónica que impidiera representar seres vivos.

Desde este punto de vista es interesante señalar la existencia en la Tradición ${ }^{71}$ de un hadit que probaría que las imágenes en sí no eran el objetivo de la censura: Mahoma destruyó uno por uno los ídolos que rodeaban

69 Puerta, , Op cit. págs. 94-95.

70 FARIS, B. Sirr al-zajrafa al-islamiyya/ Essai sur l'esprit de la decoration islamique, Institute d'Égypt d'Arqueologie Oriental, El Cairo, 1952 (ed. bilingüe) págs. 10-32.

71 WENSINCK, A.J. «Sura» en Encyclopedie de I'Islam, IV. Leiden, 1993 pág. 590. y CrESWELL, A.C. "The Lawfulness of painting in early Islam» en Ars Islamica XI-XII, 1946, pág. 160. 
la Ka'aba excepto una imagen de la Virgen con Niño ${ }^{72}$ que mandó conservar y proteger. Ello indicaría que las representaciones como tales no constituían una amenaza para la vision de la fe por parte de Mahoma. Es decir, el aiconismo islámico quedaría reducido a la representación figurativa de Dios.

Ello lleva a la consideración de que estas representaciones aunque estuvieron ausentes de los edificios religiosos del Islam formaron parte de la rutina diaria de la vida cortesana. Por esta razón se manifestó una particular preferencia por la representación de aquellos animales que habían sido utilizados como símbolos del poder real, como el león, el ave de rapiña, el águila, etc... que podrían evocar los pasatiempos de los soberanos, como las escenas de caza o los de origen astrológico.

En este punto debe insistirse en que las prohibiciones no se hallan en el Corán, sino en la Sunna.

Finalmente, lo que hemos querido demostrar en este trabajo es la enorme cercanía entre el hombre y el animal en el mundo islámico, comprobando que el animal entra de lleno en el mundo sagrado del Islam. Esa relación hombre-animal no podemos estudiarla sin referirnos a los textos sagrados que sucintamente presentamos aquí, en cierto modo de forma descriptiva pero única puesto que es la primera vez que los animales se han ido extrayendo de cada uno de esos textos, recopilándolos uno a uno, como base ineludible para abordar con profundidad un estudio posterior que aporte fuentes inéditas o desconocidas.

Esta es nuestra aportación, la primera piedra de un conjunto que puede resultar original y sorprendente.

72 Probablemente obra de algun no-árabe o del primitivo arte popular local. 